\title{
DIAMONDS OF THE URALS MOBILE BELT AND SOURCE ROCKS FOR THE URALIAN (BRAZILIAN) TYPE DIAMOND PLACERS
}

\author{
L.I.Luk'yanova $^{1}$, L.P.Lobkova ${ }^{1}$, V.V.Zhukov ${ }^{2}$, A.Ya.Rybal'chenko ${ }^{3}$, V.P.Ostroumov ${ }^{4}$.
}

1 VSEGEI, 199106, Sredney pr. 74, St.Petersburg, Russia

2 VNIIOkeangeologiay, 190121, English pr. 1, St.Petersburg, Russia

3 Committee "Perm'geologiya", Perm', Kamchatskaya st. 7, Russia

4 TOO "Prognoz", 450000, Octouber Revolution st. 10, Ufa, Russia

The Urals is the classic region for economic diamond placers. The origin of the placers was not clear till the recent time.The traditional tectonic concept of the region as a geosynclinal mobile belt provided no way to hypothesize existence of diamond-bearing kimberlites. New data on the deep structure and magmatism of the Ural Region were obtained in the course of the performed research. Those data provide to identify probable sources of placer diamonds.

New data provide to think that some regions of Urals, especially of its western slope are intercontinental rift type structures on the platform basement.Alkaline - ultrabasic magmatik manifestations of variable ages are related to these structures kimberlites, lamproites as well as diamond-bearing rocks of a new type have been discovered recently in many regions of the Urals. The latter are tuffizites and xenotuffizites which contain diamonds of the Uralian type. These rocks are hypothesized to be source rocks for placer diamonds.

Dikes and diatremes of ultra-potassic basic and ultrabasic rocks Mesozoic in age close in composition to sanidine lamproites have been examined in the Chernyshov Range (the Polar Urals). [Luk'yanova L., Derevyanko I., Dymnikova N., et al.,1993.]. High content of $\mathrm{Cr}$ - diopside, omphacite, perovskite, pyrope, picro-ilmenite have been discovered in the alluvium within the area and diamonds have been found here. This region seems to be promising for discovery of kimberlite type and lamproite type deposits. A stock and a number of dikes of kimberlite intruding Ordovician rocks have been discovered near to the Polar Urals. They are massive, porphyric, not often autolithic in fabric with xenolithes of ultramafic rocks and of eclogite.[ Luk'yanova L., and Bel'skii A., 1987.]. Kimberlites are amphibolized and carbonatized. Halos of associated minerals (exclusive of pyrope) have been mapped and crystals of diamond have been found in alluvial deposits within the area. Numerous placers of rounded diamonds of the Uralian (Brazilian) type are known in the Northern Urals in the Polyudov Kryazh area. Tuffizites, xenotuffizitess and sandy tuffs containing similar diamonds were discovered here in 1995-1996.[ Rybalchenko A., Kolobyanin V., Luk'yanova L., et al., 1997.]. Tens of intersecting veins showing branchy pattern, linear stockworks, and stratimorphic bodies up to $2 \mathrm{~km}$ long and 1-2 m to several tens of metres thick as well as diatremes up to $150 \mathrm{~m}$ in diameter have been discovered. In many cases the bodies are positioned in the bedrock beneath the placers and their location is controlled by intersections of deep sublatitudinal structures with longtitudinal interstratal strike-slip thrust faults. The bodies penetrate the rocks from the upper Riphean to the Carboniferous and have been changed by post-magmatic fluidal-metasomatic processes (agillitizaion, silification, ferruginization, carbonatization, and other). Now the rocks are argillizated breccia, microbreccia, or sandy-argillaceous rock of tuff appearance. Tuffizites, xenotuffizites, and sediments injectioned by tuffizite material can be identified. The rocks are characterized by fluidal and linear structures, by the presence of resorbed xenogenic material, by autolith-like features, by the pseudomorphosed phenocrysts of mica, pyroxene, 
olivine and illite-smectite matryx. Carbonates, titanium and manganese minerals, oxides and hydrooxides of iron, sulphides are present as an admixture. Xenogenic material is represented by quartz, fragments of sandstone, quartzite, more rarely - by fragments of felspar and other. Large xenolithes of carbonaceous and terrigenous host rocks are broken and penetrated by veinlets of tuffisites. The identification of tuffisites and of their initial composition is difficult because of intense secondary alterations. Initial rock is not presented in the results of chemical analyses. The content of indicative elements $(\mathrm{Rb}, \mathrm{Zr}, \mathrm{Y})$ and $\mathrm{K} / \mathrm{Rb}$ and $\mathrm{U} / \mathrm{Th}$ ratio allow to suggest their primary alkaline ultrabasic composition. Diamonds and associated minerals have been found in all types of volcanites. Diamonds are presented by dodecahedroides, often - by flattened, colourless, yellowish and pinkish crystals and their fragments. Black inclusions and spots of pigmentation have been reported in some crystals. Heavy minerals fraction of volcanites consists mostly of limonite, hematite and pyrite. Clynopyroxenes (diopside, salite, omphacite), orthopyroxene, olivine, garnets (pyrope, almandine. spessartine-almandine, uvarovite), aggregates of omphacite and garnet (eclogitic paragenesis), chromespinellides, ilmenite, picroilmenite, armalcolite, titanomagnetite, moissanite. barite, sulphides of zinc and lead, minerals of manganese, florencite, native iron, native gold (containing admixtures of $\mathrm{Ag}$. $\mathrm{Cu}$. $\mathrm{Hg}$ ), mercury, silicium are present in small amounts. Ball-shaped mineral aggregates - spherites - are constantly present. They have surface hardening incrustation composed of amorphous alkaline-alumosilicate matter. Carbonate-manganese-ferruginous and titano-ferruginous spherites of zonal structure are usual. The cores of the spherites are composed of native iron, the middle parts - of titanomagnetite. ilmenite, picroilmenite, the periphery - ferrotitanates including rutile. Spherites composed by amorphous alkaline-ore-silicate matter are frequent. Sometimes this matter dissociation pattern with ilmenite phase containing $\mathrm{MnO}$ up to $11-17$ per cent. Spherites composed of aggregate apatite and chrome-spinellide are present as well. Pyropes of the dunite-harzburgite and lherzolite paragenesis are present as oval and irregular grains up to $2 \mathrm{~mm}$ with corroded and sculptured surfaces. Chromespinellide of variable composition (including high-chromous of the adamantine paragenesis. manganese, zinc, and vanadium-bering) form octahedronic crystal with smoothed tops and edges, and rounded and irregular grains 0,05-2 $\mathrm{mm}$ size. Picroilmenite, often with a high content of chromium, occurss as fattened crystals and oval grains(see table). Lamproite dikes of three varieties (diopsideolivine-phlogopite, leucite-olivine-phlogopite, and olivine-phlogopite) have been mapped in the South Urals, in the Magnitogorsk-Verkhneuralsk Region.[ Luk'yanova L., Mareichev A., Mashchak I.. et al., 1992.]. High pressure minerals (pyrope, picroilmenite, chrome-spinnelide) chemically characteristic of diamond-bearing lamproites in Australia are present in the olivine - flogopite variety. $\mathrm{Rb} / \mathrm{Sr}$ age of this complex is 197-240 my. The emplacement of lamproites is the final stage of Paleozoic-Mesozoic alkaline magmatism connected to tectonic and magmatic activization of the Magnitogorsk Sinclinorium and the Eastern Urals Rise. This region of the Urals is promising for discovery of bedrock deposits of the lamproite type diamonds.

\section{Concluseions}

The Ural Mobile Belt is extremeli promising for discovery of bedrock deposits of diamond of a kimberlite, of a lamproite and of a new (tuffizite) types. Prosspecting aimed to discovery of the latter type should not be limited to the Ural Mobile Belt area. It is realastic that similar type volcanites can also be found in those regions of the world where diamond placers of the Uralian (Brazilian) type are known. 


\section{Prognosis}

Structural-tectonic position, morphology of the bodies, and characters of the composition and of the fabric of these rocks can serve as criteria for prospecting and prediction of diamond - bearing tuffizites in other regions.

Composition of certain minerals of xenotuffisites from the Krasnovishersk district of the Urals, wt $\%$.

\begin{tabular}{|c|cccccccccc|}
\hline no & $\mathrm{SiO}_{2}$ & $\mathrm{TiO}_{2}$ & $\mathrm{Al}_{2} \mathrm{O}_{3}$ & $\mathrm{Cr}_{2} \mathrm{O}_{3}$ & $\mathrm{Fe}_{2} \mathbf{O}_{3}$ & $\mathbf{F e O}$ & $\mathrm{MnO}$ & $\mathrm{MgO}$ & $\mathrm{CaO}$ & Total \\
\hline \multicolumn{7}{c}{} & & & \multicolumn{7}{c}{ Chrome-spinels } & & & & \\
1 & 0.48 & 0.65 & 2.54 & 67.22 & - & 21.77 & - & 7.32 & - & 99.98 \\
2 & 0.41 & 2.42 & 2.77 & 64.51 & - & 22.23 & - & 7.69 & - & 100.03 \\
3 & - & - & 5.87 & 63.65 & 3.19 & 16.74 & - & 10.48 & - & 99.93 \\
4 & 0.38 & 0.57 & 12.68 & 62.63 & - & 14.59 & - & 9.64 & - & 100.59 \\
5 & 0.41 & 1.09 & 20.43 & 58.86 & - & 13.04 & - & 7.49 & - & 101.32 \\
6 & 0.52 & 4.39 & 6.72 & 49.59 & 7.31 & 19.89 & - & 11.47 & - & 99.89 \\
7 & 0.33 & - & 13.81 & 42.07 & 13.06 & 23.70 & - & 6.90 & - & 99.87 \\
8 & - & 2.20 & 12.71 & 37.66 & 16.28 & 19.61 & 2.68 & 8.71 & - & 99.85 \\
9 & - & 1.05 & 12.43 & 34.20 & 20.59 & 24.96 & 1.07 & 5.50 & - & 99.81 \\
10 & - & 0.32 & 7.52 & 53.77 & 8.72 & 20.23 & 2.49 & 6.85 & - & 99.99 \\
11 & 0.05 & 0.18 & 5.65 & 65.60 & 2.22 & 14.00 & 0.33 & 12.60 & - & 100.63 \\
12 & - & 0.16 & 5.74 & 68.80 & - & 14.70 & 0.53 & 11.60 & - & 101.53 \\
& & & & & Ilmenites & & & & & \\
13 & - & 49.30 & - & - & - & 43.47 & 1.84 & 4.21 & - & 98.92 \\
14 & - & 46.83 & - & - & - & 49.36 & 2.46 & - & - & 98.65 \\
15 & - & 42.40 & 0.36 & 5.89 & - & 42.10 & - & 7.16 & - & 97.91 \\
16 & - & 50.09 & 0.40 & 6.29 & - & 31.24 & - & 11.14 & - & 99.16 \\
& & & & & Garnetes & & & & & \\
17 & 41.00 & - & 16.13 & 11.55 & - & 7.37 & - & 18.68 & 5.39 & 100.12 \\
18 & 41.40 & - & 16.98 & 11.03 & - & 6.08 & - & 22.09 & 2.48 & 100.06 \\
19 & 41.45 & - & 17.48 & 8.71 & - & 6.87 & - & 18.77 & 6.75 & 100.03 \\
20 & 41.55 & - & 20.70 & 5.23 & 0.33 & 5.39 & 0.54 & 22.06 & 3.77 & 99.57 \\
21 & 42.26 & - & 21.50 & 4.80 & - & 5.85 & - & 22.23 & 3.40 & 100.04 \\
\hline
\end{tabular}

Note: Microprobe analyses were performed at VSEGEY (CAMEBAX; Yacovleva O.A., analyst); (11-12) - [5]

\section{References}

1. Luk'yanova L., Derevyanko I., Dymnikova N., et al.,1993.Dokl. Ross. Akad. Nauk, vol. 330. No. 5. Pp.617-619.

2. Luk'yanova L., and Bel'skii A., 1987. Sov. Geol. No. 7, pp.92 - 102.

3. Rybalchenko A., Kolobyanin V., Luk yanova L., et al., 1997. Dokl. Ross. Akad. Nauk, vol. 353. No.

2. Pp. $223-226$.

4. Luk'yanova L., Mareichev A., Mashchak I., et al., 1992. Dokl. Ross. Akad. Nauk, vol. 324. No. 6. Pp. $1260-1264$.

5. Shemanina E., and Bogomol'naya L., 1980. Tr.TsNIYRI., no. 153. Pp.89 - 95. 